\title{
Disease and intercolonial relations: small pox in the British Caribbean, 1902-1904 ${ }^{1}$
}

\author{
Rita Pemberton \\ The University of the West Indies \\ St. Augustine, Trinidad and Tobago
}

The outbreak of epidemic small pox in the Caribbean at the beginning of the $20^{\text {th }}$ century aggravated the problems inherited from the $19^{\text {th }}$ century posing further challenges for these territories. This study discusses the bitter controversy that it stimulated between Barbados and Trinidad and examines the course of and response to, the disease in both colonies. It is argued that the underlying economic and social implications of the epidemic underscore the relationship between trade and health and demonstrate how regional cooperation was possible even in the midst of rivalry.

Key words: Disease; smallpox; public health; controversy; quarantine; trade; intercolonial relations.

\section{INTRODUCTION}

The significance of disease in history has been demonstrated by the recent outbreak of Chikungunya in parts of the Caribbean since June 2014 putting the Caribbean countries on preventative alert. First reported in St. Maarten, the disease spread through the region with consummate ease despite the hasty announcement of anti mosquito campaigns, public sensitization programmes and other prevention measures. Close on the heels of this scare came the more

\footnotetext{
1 This work has been realized in the research Project of Plan Nacional del MINECO (España) HAR2012-37455-C03-03.
} 
terrifying ebola panic as this deadly disease assumed epidemic proportions in the West African countries of Guinea, Liberia and Sierra Leone. With the relative ease of global travel, there were concerns that the disease could land on the Caribbean shores. While keeping abreast of the progress of the disease via the international media, public panic could be read in the local newspapers which were replete with comments, criticisms and exhortations from readers on the nature and (in) adequacy of the preparations in the region. These contemporary instances replicated the scenario of yesteryear when terror and consternation gripped the region's population during earlier epidemics particularly the cholera epidemic of the 1850-1855 and the smallpox epidemics of 1870 and 1902/03. Underscoring the present panic are the questions of isolation and quarantine, issues which are replays of concerns in the region since the $2^{\text {nd }}$ half of the $19^{\text {th }}$ century when basic infrastructure was virtually absent and untrammelled movement was the norm.

The unregulated movement of people, plants, animals and ships has been a feature of life in the Caribbean since the advent of the Europeans. Because the connection between this movement and the transfer and spread of diseases was not recognized, official interest was focused on regulating the nationality of the ships coming into port and their rights to trade rather than on their human and other contents. The earliest controls on people were applied to indentured immigrants from India who were quarantined until they were deemed fit enough to undertake estate labour. After the 1850-1855 cholera epidemic there was increased concern about quarantine but the first initiatives were focused on animals, especially horses, before a system was devised to deal with infected people and specifically with those afflicted with infectious and communicable diseases.

Although the historiography of health in the British Caribbean is increasing there remains major gaps in the literature. While there is passing mention of epidemic outbreaks, a lacuna of detailed information and discussion of specific health episodes persists. This chapter examines one such episode, the eruption of epidemic smallpox in 1902/1903, to show how the issues of isolation and quarantine assumed prominence in the Caribbean region and discuss their impact on trade and inter-colonial relations at that time. Focus is placed on the trajectory in the colonies of Barbados and Trinidad and Tobago where newspapers covered the raging medical controversy that developed over the epidemic between combatants from these two colonies. However, the newspaper coverage was regional as the epidemic spread to other Caribbean territories and these developments were relevant to the main conflict.

The newspapers constitute an invaluable source for this research because the main participants in the conflict used the newspapers to air their grievances and to explain their positions. Therefore the newspapers not only provide information 
on the subject but they also transmit sentiments, tensions and emotions that were aroused by the conflict. These constitute an important window, which makes it possible to properly contextualize the episode. It is also necessary to view the epidemic in its social and economic context which is outlined in the next section.

\section{BACKGROUND}

At the beginning of the $20^{\text {th }}$ Century, the territories which constituted the British colonized Caribbean faced a number of challenges. Primarily dependent on a sugar economy, they faced stiff competition on the international markets which forced Montserrat and the Windward islands out of sugar production. The remaining territories had to modernize and seek new markets for their produce. Of these Trinidad and Guyana were the strongest performers, followed by Barbados, St. Kitts and Antigua. Along with the fact that its sugar industry had recovered from depression by $1900,{ }^{2}$ Trinidad was assisted by its expanding cocoa industry and its growing commercial sector. The Trinidad economy was therefore in a healthier position than that of most other British Caribbean territories. Barbados remained heavily dependent on sugar production and faced a slump in trade as a result of displacement by the expansion of the sugar industries of Cuba and Puerto Rico, which contributed to the hardship experienced by the poorer classes. ${ }^{3}$

During the last decade of the $19^{\text {th }}$ century, drought especially, the drought of 1894-95, which had "desiccated black workers' subsistence grounds-compounded the local misery already created by economic depression" 4 in Barbados. Along with the Windward islands-Grenada, St. Lucia and St. Vincent, Barbados faced economic depression, which, according to Bonham Richardson, lasted from 1884-1902. ${ }^{5}$ Public revenue of these four islands primarily came from import duties on foodstuff, which amounted to "well over half the annual revenue for both Barbados and St. Vincent and sometimes more than half for St. Lucia." "During the depression years this source of revenue dwindled significantly sending these territories into a downward economic spiral, upsetting longstanding debt and credit relationships, affecting all levels of the society, bringing St. Vincent almost to bankruptcy. ${ }^{7}$

\footnotetext{
2 Brereton, 1981: 205.

3 Beckles, 2006: 205.

${ }^{4}$ Richardson, 1997: 1.

5 Ibidem: 2.

6 Ibidem: 55.

7 Ibidem: 56-57.
} 
In an attempt to stave off depression, at the end of the $19^{\text {th }}$ century Barbados devised migration schemes to export some of its "surplus population" to the Windward Islands. Since they too faced the restrictive constraints of depression, this Barbados initiative was unsuccessful. Migration to Trinidad became a popular avenue for people in the Eastern Caribbean seeking employment and better opportunities. However, even the main sugar producers were faced with low prices and in turn they offered extremely low wages to their workers who lived and worked under appalling conditions contributing to the social outbursts in the region: 1885 in Grenada, 1891 in St. Vincent, 1896, St. Kitts and Guyana; 1898, Dominica and Montserrat; 1902, Jamaica and Guyana and 1903, Trinidad. The distress that caused complaint to the imperial government, led to the establishment in December 1896 of the Royal Commission to the West Indies, 1897 (the Norman Commission). This commission recommended inter alia that the dependence on sugar production should be reduced, agricultural diversification and agricultural education should be promoted, more scientific agriculture should be practised and peasant agriculture should be encouraged.

Social problems which were evident in the last three decades of the $19^{\text {th }}$ century remained pervasive in the early $20^{\text {th }}$ century. Poor living and working conditions were mirrored across the region in the better off, as well as in the badly off economies. In addition to the epidemic, Trinidad faced a major fire in the city and the Water Riots (March1903), and St. Vincent suffered from the twin disasters of the hurricane in 1898 and the volcanic eruption of Mt. Soufrière in May 1902. These added to the economic woes of the territories and they dramatized the prevailing social conditions. A marked feature of the region was the poor state of infrastructure particularly in the crowded areas of the main towns which made their occupants prone to epidemic disease and health problems.

The smallpox epidemic began in Barbados in February 1902, erupted in Trinidad in October 1902, although there was no official admission from the Trinidad government, and spread to Jamaica, Guyana, Dominica, Grenada, St. Lucia and St. Vincent by the time it had run its course in Barbados. The following section provides a detailed account of the course of this epidemic in Barbados.

\section{The Smallpox Epidemic in Barbados}

In February 1902, the authorities in Barbados announced the outbreak of a smallpox epidemic on the island. A report in the Barbados Gazette stated that the epidemic began with the importation of an affected person into Barbados from 
Canada. As required, the rest of the region was notified of the outbreak of an infectious disease on 23 February $1902 .{ }^{8}$ Cases in the outbreak, which occurred in two phases on the island, totaled 1,466 with 119 deaths. ${ }^{9}$ The introduction of the disease to the island was blamed on lax quarantine arrangements as there were no quarantine restrictions on ships entering Barbados from England, USA and Canada. Thus, entry to the island of the afflicted patient who was diagnosed on 23 February and died two days later, was permitted. Lacking both a medical officer of health to manage such an operation and isolation facilities to contain the epidemic, measures had to be put in place while the epidemic was already raging. On $24^{\text {th }}$ February the Barbados Board of Health established Pelican Island as an isolation facility with Dr. Bridger, medical officer in charge of the troops in Antigua, in charge of the hospital. A law requiring the isolation of infected persons and their families at Pelican Island was passed at the same time. ${ }^{10}$

Meanwhile, the disease spread rapidly as the contacts of the initial case and their contacts, developed the disease. Stunned by both the outbreak and the level of unpreparedness of the health system for an occurrence of that nature, the Barbados community reacted with disbelief and non co-operation while the authorities instituted a number of panic legislative and facility provision measures. Intending to curtail any further spread of the disease, isolation units were established in school buildings and on May $10^{\text {th }}$, the first Vaccination Bill, requiring all parochial medical officers to be provided with lymph by the government, to vaccinate all paupers free and other parish residents for a charge of 6d., was passed. Amidst a prevailing "false sense of security" these measures proved useless and casualties to small pox continued to mount in the slums of Bridgetown. ${ }^{11}$

The need for vaccination was very great. There was no system in place when the epidemic occurred. At that time public vaccination was available only to the upper classes and a reserve supply of vaccines was kept for epidemic emergencies elsewhere. A system for mass public vaccination had to be hastily established in the midst of the crisis. ${ }^{12}$ This was to be no easy task as the absence of a vaccination culture on the island led to popular skepticism. There was opposition to mandatory isolation, which was seen as a violation of the liberties of the individual. The resulting popular lackadaisical and hostile

\footnotetext{
${ }^{8}$ Report on the Small pox Epidemic in Barbados, 1902-03, The Official Gazette, The National Library, Bridgetown, Barbados: 1492.

9 Ibidem: 1493.

10 Ibidem: 1494.

11 Ibidem: 1495.

12 Ibidem, Appendix, Report of the Poor Law Inspector, Dr. John Hutson, 1904.
} 
attitude to the epidemic and government measures was fanned by the antivaccination literature, which appeared in the press. ${ }^{13}$

The situation is well described in the November 221902 letter to the Editor by Enquirer who stated that "Barbados rocked for four month" under a disease called "glasspox, chicken pox, cowpox and even India pox but not smallpox..." as "press and community in Barbados did not want to accept that smallpox was on the island." 14 The writer asserts that there was strong denial of the presence of the disease on the island until the end of August.

The district that was hardest hit by the epidemic was Baywood Village in the parish of St. James, where the majority of the 2,200 residents were unvaccinated. The disease spread rapidly from 24 centres through the cluster of homes located below Apex Hill plantations with cases totaling 438 with 33 deaths in this area. ${ }^{15}$ The temporary wards created at Pelican Island could only accommodate 248 patients. As the epidemic spread, Pelican Island was mainly used for cases in Bridgetown and schools were used to create isolation facilities in the parishes of St. Phillip, Christ Church, St. James and St. George. ${ }^{16}$

The measures instituted to control the epidemic were centred on: isolation and removal of patients to hospital; disinfection of houses occupied by infected persons; vaccination of the surrounding hospitals; house to house inspection of the infected districts -in three or four cases infected houses were burnt- and the payment of incentives. Rewards of 10 shillings, later $£ 1$ pound, were offered for information on new cases. ${ }^{17}$ Despite these measures the epidemic spread to all parishes on the island but was most severe in St. James and St. Michael.

On February 261903 The Barbados Public Health Amendment Act was passed. This law authorized the Commissioners of Health to declare any parish infected with smallpox and restrict movement of persons from the infected area unless they were vaccinated or disinfected. These restrictions met with strong public opposition and infected persons slipped through the quarantine fence to visit their friends and relatives. So strong was the opposition to the restrictions that in some cases police intervention became necessary. ${ }^{18}$

13 Ibidem: 1494.

${ }_{14}$ Enquirer, Barbados Globe and Colonial Advocate, (Bridgetown, January 5 1903): 3.

${ }_{15}$ Report on the Outbreak of Smallpox in the parish of St. James, August to November 1902 by R. L. T., Archer Parochial Medical Officer in Report on the Small pox Epidemic in Barbados, 1902-03, Appendix VIII: 1515.

${ }^{16}$ Report on the Small pox Epidemic in Barbados, 1902-03, The Official Gazette, The National Library, Bridgetown, Barbados: 1497.

17 Ibidem: 1498.

${ }^{18}$ Ibidem: 1499. 
The Vaccination Act of 10 May 1902 proved ineffective and the vaccination Amendment Act of 22 August 1902 appointed all druggists and medical practitioners as public vaccinators. By this measure, 259 Vaccinators were appointed for an unvaccinated population of 196,000. While there was some opposition to non-medical appointees, the Vaccination Further Amended Act passed 29 October 1902, offered a bonus of 6 pence to each vaccinator and patient that was successfully vaccinated or revaccinated ${ }^{19}$ and on 29 March 1903 the Infants Vaccination Act was passed putting vaccination by unqualified persons as public vaccinators on a permanent basis. ${ }^{20}$

Of the 1,466 smallpox cases on the island 747 were treated in isolated private premises and 719 at Pelican Island. ${ }^{21}$ The epidemic cost the island $£ 19,2392$ s. $3^{1 / 2}$ d. These costs included payments to the Sanitary Commissions of the parishes other than St. Michael, St. Paul and St. Thomas, which gave pro bono services. ${ }^{22}$ The epidemic was officially reported as ended on $20^{\text {th }}$ April 1903 when the last two patients were discharged from the Pelican Hospital. ${ }^{23}$ The official Barbados response to the epidemic was in accordance with the existing regional agreement described below.

\section{Regional Quarantine ArRangements}

Quarantine laws in the British Caribbean were governed by the agreements made at the Quarantine Conference, 1-3 October 1888. Seeking to formulate a unified system, delegates agreed that the detention of ships and crew without a system of disinfection was useless. Cholera, yellow fever and small pox were declared infectious diseases which required the application of quarantine regulations for a specified period. A port or place would be declared infectious if cases of yellow fever occurred in three consecutive weeks and more than one case of cholera or small pox occurred in a house. Information on infectious diseases was to be interchanged between the colonies. An outbreak of an infectious disease in any colony was to be declared, steps for disinfection taken

${ }^{19}$ Extract from the Proceedings of the Barbados House of Assembly on 27 January, 1902, National Archives, Kew, London (NA). CO 28/260. Enclosure No. 4 in Confidential dispatch of 30 January 1903.

${ }^{20}$ Report on Smallpox Epidemic in Barbados, 1500, The Official Gazette, BNA, (Bridgetown, 1903): 1500.

${ }^{21}$ Ibidem: 1502.

22 Ibidem: 1503.

${ }^{23}$ Ibidem: 1492. 
and ships quarantined in the public interest. ${ }^{24}$ The onus was on the affected country to make the declaration and inform the rest of the region. It was the responsibility of the other territories to respect the quarantine regulations and declare and the imposition of quarantine against the infected territory. These restrictions meant that trade and communication with the afflicted area would be curtailed for the duration of the quarantine period.

As a result of its declaration, the remaining Caribbean colonies, including Trinidad and Tobago, imposed quarantine restrictions on Barbados for nearly a year, seriously disrupting the island's trade. While Trinidad was also gripped by a similar epidemic, the train of events there, differed from that of Barbados.

\section{SMallpoX Alleged: the TRINIDAD PHASE}

there was no formal announcement from the authorities in Trinidad about the existence of an infectious disease in the colony. There was therefore no official reporting on the progress of the disease in the Trinidad with the detail to be found in the case of Barbados, it being assumed by the Trinidad authorities, that the health occurrences there were "normal" and posed no serious health risks. In fact, official reporting on the epidemic came in response to questions posed by the government of Barbados as it sought to verify the persistent rumours about the disease in Trinidad.

Information of the Trinidad epidemic were carried in a report by the Surgeon General, the chief medical officer for Trinidad and Tobago of an outbreak of a disease, which made its first appearance in Duncan Street in the capital, Port of Spain, in October 1902, and then spread to other parts of the town. ${ }^{25}$ Some cases of the disease were traced to the ports of Carupano and Yrapa in Venezuela, where a similar disease was prevalent. Between January and October 1903 there occurred 19 cases of eruptive fever, (which medical practitioners on the island could not definitely identify) all of which were attended at the Port of Spain Hospital. Ordinance 11 of 1893 was proclaimed and temporary isolation hospitals were established in Port of Spain, San Fernando, Chaguanas, Cedros, Tunapuna, Toco, Flanagin Town and in No.3 district of Tobago and as an incentive to locate cases, doctors were paid

${ }^{24}$ Pemberton, 2006: 115-117.

${ }^{25}$ Minutes and Proceedings of the General Board of Health. Statement by the Surgeon General on Cases of Eruptive Fever in Port of Spain, National Archives of Trinidad and Tobago (NATT), Trinidad Royal Gazette, (Port of Spain, 19 Feb. 1903): 243-244. 
2 shillings for every case that was successfully treated ${ }^{26}$. But precisely what was this mystery disease that was spreading through the city?

Medical opinion in the colony varied. Save for one officer, the prevailing view was that the disease was not smallpox. The Surgeon General expressed the opinion that the disease was either Indian pox or severe varicella ${ }^{27}$ and he ordered all physicians operating in the town to report all cases which came before them. These were to be followed up by house-to-house inspection of all affected cases. The disease raged through Port of Spain and in his annual report for 1903/04 (after the epidemic had been spent), the Surgeon General revealed that 4,335 cases and 27 deaths were known to have occurred in the capital, a case mortality of $.54 \% .{ }^{28}$ Still for the Trinidad authorities, it remained an unidentified mystery disease.

But there were rumours circulating in Barbados that a disease similar to the one in Barbados was raging in Trinidad and that the government had instituted some isolaton measures. The frequency of such rumours prompted the Governor of Barbados to address a telegram to his Trinidad counterpart seeking clarification of the matter. The different positions of the administrations of these two colonies over the outbreak of this disease sparked "a bitter controversy" 29 that was manifested in a vitriolic verbal battle that was fought out on the newspaper battleground.

On Monday 3 November 1902, the Barbados Globe and Colonial Advocate reported that in reply to a telegram from Sir Frederic Hodgson. Sir Courtenay C. Knollys, acting Governor of Trinidad, has denied by telegraph that smallpox exists there.

The Governor of Barbados, prodded by the many reports he received about the epidemic in Trinidad ordered the publication of the communication between himself and the Acting Governor of Trinidad as follows:

From the Governor of Barbados dated 31 October 1902:

Letters sent from Trinidad state definitely temporary hospital arrangements are being made for the treatment of persons suffering from some infectious disease, and that articles in contact with these persons are being fumigated and disinfected. Please inform me by telegraph if any foundation for either or both statements.

\footnotetext{
${ }^{26}$ Pemberton, 2013: 114.

${ }^{27}$ Minutes and Proceedings of the General Board of Health. Statement by the Surgeon General on Cases of Eruptive Fever in Port of Spain, NATT, Trinidad Royal Gazette, (Port of Spain, 19 Feb. 1903): 243-244.

${ }_{28}$ Trinidad and Tobago Council Paper No. 75 of 1904, Annual Report of the Surgeon General for 1903/1904, NATT, 4.

${ }^{29}$ Seheult, 1948: 3.
} 
From Acting Governor of Trinidad to the Governor of Barbados:

"...referring to your telegram of 31st October no foundation for statements." W.K. Chandler Colonial Secretary, Acting. ${ }^{30}$

The publication of this communication, which made the issue fully public, was in fact a battle cry. There were strong doubts in the minds of Barbadians about the truth of the Trinidad response and there were equally strong sentiments on the circumstances of the Trinidad outbreak. The airing of the communication for public consumption strengthened the determination of both parties in the conflict to hold to their position. In Barbados, it did result in putting the Trinidad administration in a very negative light strengthening their resolve to prove their point.

Doctors in both territories used the cover of the newspapers to vent their emotions. Barbadians paid very close attention to developments in Trinidad, following and responding to the contents of Trinidad newspapers to demonstrate that the Trinidadian authorities were less than honourable in their dealings on the matter. The newspaper report continued:

With the honour due to the source from which the denial comes we are bound to shut our ears to all the unauthoritative statements made and accept the denial; but the awkwardness of the situation must be admitted when it is remembered that the rumour did not issue from one quarter alone, but was confirmed by individuals wholly unknown to each other and abiding in various stations of life in Trinidad. ${ }^{31}$

Despite being couched in carefully selected diplomatically correct language, the message was clear. Barbadians believed that the Trinidad authorities were lying.

\section{Controversy Rages}

Barbadian writers took pains to explain that they were seeking the honourable truth rather than trying to pull Trinidad down. Asserting that they did not want to be blamed for wanting Trinidad to fall "in the same rut as ourselves" one writer was anxious to assure their neighbours of the "persistency and seeming reliability" of the information they received despite the denial of the Trinidad Governor. The newspaper report stated further that:

\footnotetext{
${ }^{30}$ Barbados Globe and Colonial Advocate (BGCA), (Bridgetown, 3 November 1902): 3.

31 Idem.
} 
From a recent issue of The Gazette received this morning, it does appear that much attention has been devoted to extreme care in sanitation pointing to the insanitary state of Trinidad. The Gazette noted the unsatisfactory state of sanitation in the colony despite the "ridiculously untrue" picture painted by the sanitary reports. But "The frequent exposure by the Press of this colony of the risk we were running of an infection from Barbados rendering Port-of-Spain a perfect plague spot was more than once seized by our contemporaries in the sister colony as proof that our acknowledged insanitary condition made us ultra- sensitive to the danger of infection. To a limited extent that was doubtless so; and it is a matter for much regret, and not a little indignation, that our Government should still be so wanting in a sense of their duty as to have practically taken no active steps for immediately placing Port-of-Spain on a more satisfactory sanitary footing... ${ }^{32}$

Undoubtedly, the sanitary condition of Port of Spain was unsatisfactory and certainly not what was expected in a colony that was as economically favoured as Trinidad was at that time. Not even in the face of an epidemic were the colonial authorities moved to institute any measures to improve the quality of life for the working and poorer class. Hence the label of an uncaring colonial administration was truly an appropriate description for the Trinidad authorities in this instance.

It, however, became very clear that Barbadians were not prepared to let the matter rest until the truth was told. A later issue of the newspaper carried an article, under the heading: "Glasspox- No Fear", which commented on the problems the medical fraternity in Trinidad encountered in naming the disease that was prevalent on the island. It stated:

We find, by a recent issue of The Mirror that our friends in Trinidad are not so sure after all that "'the rumour was unfounded" as Sir Courtenay Knollys, (the Acting Governor of Trinidad) was pleased to write to our Governor on the 1st instant, in reply to a query from Barbados whether the rumour was true that small pox was existing at Trinidad. We find it curious that four doctors had to be called to decide on a case of "simple glass pox" and this suggests that the cases in Trinidad are similar to those in Barbados and that there is uncertainty in the matter... and wanted to know what course has been pursued as isolation would not be necessary for so simple a cause. ${ }^{33}$

The writer commented sarcastically on the different names by which the disease was called in Trinidad, (although a similar development occurred in Barbados) and restated an earlier call for a Barbadian doctor to be sent to Trinidad to investigate the outbreak there. The writer opined:

\footnotetext{
32 Idem.

33 Ibidem (19 November 1902): 3.
} 
The frequent cropping up of these Glass, Chicken, Cow and any Pox but Small pox-as the Trinidad doctors are pleased to call the disease- confirms us in our opinions expressed recently, viz, one of our doctors should be sent to Trinidad to report on the nature of the pox there. ${ }^{34}$

The writer complained about the silence of other territories on the matter and lamented:

It is expecting too much of human nature to expect the Trinidad Authorities will frankly admit the truth in this matter, seeing the enormous loss that will follow in its wake. That they should fence the truth is most natural: but that we should be silent seconds to this duel between conscience and Trinidad's advantage, is simply suicidal on our part. Our position is desperate, and we should meet sophistry with sound reasoning; and it is most reasonable to believe that from these recent and frequent happenings in Trinidad, that the island is affected with Smallpox. ${ }^{35}$

The news that cemented opinion in Barbados was the clipping from a Trinidad newspaper which stated:

Considerable excitement was caused on Sunday by the report that smallpox had appeared at 45 Duncan Street. On the report being made to the authorities, Dr. Knox, the Surgeon General, Dr. Dickson, Dr. Masson and Dr. Lotta all visited the cases and we are glad to be able to say that the disease is not smallpox, but a simple and common cutaneous eruption known as glasspox. ${ }^{36}$

Sentiments ran high in Barbados and this is reflected in a letter to the Editor from Enquirer stating that:

Trinidadians had halfheartedly admitted that theirs was a kind of disease they called glass pox which resembled variola. The disease stimulated isolation and strict police surveillance which created suspicion. ${ }^{37}$

The writer also supported the suggestion to send down an investigator from Barbados but observed that Trinidadians remained silent on the matter as "their lives depends on it." while Barbados "rocked for four months." 38

Reports reaching Barbados revealed that up to Monday January 5 1903, there were 1,591 cases of the disease in Trinidad, which resulted in 112 deaths.

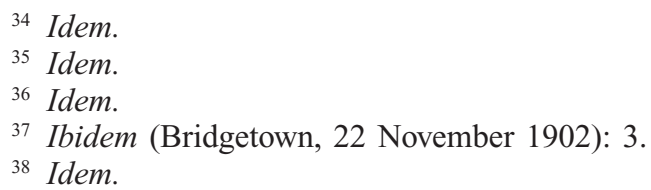

${ }^{35}$ Idem.

${ }^{36}$ Idem.

37 Ibidem (Bridgetown, 22 November 1902): 3.

38 Idem. 
There were121 persons who were discharged as cured and between Saturday 27 December 1902 and Friday $2^{\text {nd }}$ January 1903, there were 5 cases, no reports of deaths and 25 discharges who were said to have been cured. ${ }^{39}$

The precise nature of the information reaching Barbados suggests that it emanated from well-placed sources and was not based on casual malicious rumours. It does indicate that something was amiss in Trinidad. An infectious disease, which was spreading rapidly through the poorer districts of Port of Spain with a significant mortality rate, had not captured the attention of officialdom in that island and had not been considered important enough to be brought to the attention of other regional governments. To Barbados, this was a very serious matter for which answers were imperative.

The Barbados House of Assembly passed a strongly worded resolution asking the Governor to send an investigator to determine whether there was any truth in the rumour that Trinidad had small pox. The resolution was amended because there were concerns that it might be deemed a distasteful reflection on the medical fraternity in Trinidad. It was modified to request the Governor to take steps to find the truth but the assembly recommended an independent investigation and expressed willingness to support it with the required funding. ${ }^{40}$

Developments in Trinidad were closely monitored in Barbados. The Barbados newspaper carried an article from a Trinidad newspaper, the Port of Spain Gazette of 22 January, which claims that the disease brought from Yrapa was not smallpox as, after watching the case closely, "the usual symptoms were not observed... It may be a virulent form of chicken pox, but it has not been found to be fatal in its effects." The medical opinion was that it was not any more dangerous than measles. It occurred in people who had been vaccinated and was dissimilar as the eruptions were not the same as small pox and did not leave marks, when healed. Hence quarantine was not necessary against Carupano but the authorities remained vigilant. ${ }^{41}$

This was a reflection of the dominant medical opinion in Trinidad. As a result the authorities were not moved to action, causing much consternation in Barbados. The Trinidad interest group would not allow the Barbadian views to go unchallenged.

\footnotetext{
39 Ibidem (5 January 1903): 3.

40 Ibidem (7 January 1903): 3.

${ }^{41}$ Ibidem (4 February 1903): 3.
} 


\section{TRINIDAD Fires BACK}

The Trinidad perspective of the case was outlined in the newspaper The Pioneer in an article captioned "Barbadian Pox." In this article it was stated that Barbados complained bitterly about the difficulties it endured as a result of declaring the outbreak of smallpox. As a result, Bridgetown, the capital of Barbados, was declared an infected port and quarantine restrictions were applied against the island by the rest of the Caribbean. The writer was not at all sympathetic to the Barbados position for the article continued:

...Indeed our sister colony seems to be less deficient in cash than in common sense" for the island's House of Assembly pledged to finance an investigation into the exact nature of the few cases of chicken pox reported in Trinidad. ${ }^{42}$

Although the Trinidad authorities did not appear to object to the investigation, views in the press indicated that there were some persons who certainly did. One writer asserted:

... To say the least it is doubtful taste to so completely and publicly discredit the word of the Acting Governor and the affirmation of the Board of Health that there has been no small pox in the island. It can hardly be called honourable to endeavor to make out that one's neighbor is infected because of one's own disease, neither is it charitable to attempt to ruin a sister island, because she has successfully protected herself from infection. A less spiteful and jealous disposition would have elicited more general sympathy. ${ }^{43}$

Imputing malicious intent to the Barbadian response, continuing the myth that "she has successfully protected herself from infection" and confident that because of the resemblance between chicken pox and smallpox, the investigator would convince the Barbadian authorities that the disease afflicting Trinidad was not small pox, the writer stated: "and it would be humorous if that information had been imparted to them by one of our own medical men." ${ }^{44}$ This was an obvious reference to Dr. Masson, the lone Trinidad doctor who went against the prevailing tide of opinion and initially identified the disease in Trinidad as smallpox.

But there was no let up on the issue from the Barbadian medical community who, in an article entitled "A Nameless Disease", took their Trinidad colleagues

\footnotetext{
42 Idem.

43 Idem.

44 Idem.
} 
to task for the views expressed in an article carried in the Port of Spain Gazette of 1 February, 1903. This article reflected the hubris of the Trinidadians who chastised the "impertinence" of Barbados for sending a medical investigator to Trinidad. In response it was the Barbadian complaint that: "Trinidad mocked at our uncleanliness which she hugged to her bosom more than one hundred hidden victims groaning under similar pain." ${ }^{45}$ But it asserted that the circumstances were "fishy" as the disease was spreading uncontrollably in Port of Spain. The Pioneer supported the opinion that the disease in Trinidad and Barbados bore similarities but stated that in the case of Trinidad, it was a severe variety of chicken pox called Indian pox. As Dr. Bridger was about to arrive in Trinidad, the article stated that if he diagnosed small pox:

... it is quite possible that the Barbadian House of Assembly, who are evidently not charitably inclined towards us, will impose quarantine restrictions against Trinidad, even if we do not declare ourselves an infected port... Trinidad cannot allow itself to be quarantined if there is any doubt about the nature of the disease. We trust that should any such emergency arrive our legislature will act vigourously... ${ }^{46}$

This Trinidad writer sought to reduce the issue to an ignominious Barbadian attack on Trinidadians. In an article also captioned "Barbadian Pox" it was stated that the Trinidad medical men argued that the disease was similar to that in Barbados, but it was not smallpox. Outlining the position that Trinidad was served by a number of doctors who had experience in the treatment of the disease and were competent to identify it, the writer stated that resident practitioners, Drs. De Wolf, Boissiere and Knox, had passed through the 1870 epidemic and Drs. Lotas, Dickson, Laurence and Lasalle also had experience with dealing with smallpox. It said that the fact that there had been no deaths from the disease was the main basis for their argument that the disease was not small pox even though it continued spreading throughout the city. ${ }^{47}$

A later issue of the newspaper carried an article which identified two issues to be resolved in the conflict; whether the eruptions in cases of the disease in Barbados were similar to those in Trinidad and if they were smallpox. ${ }^{48}$ The writer stated: "We are reluctantly forced to the conclusion that a sad yet ludicious mistake has been made in diagnosing the affliction in Barbados as small pox." ${ }^{49}$ This error by the Barbadian authorities caused the Trinidad adminis-

\footnotetext{
45 Idem.

${ }^{46}$ A Nameless Disease, The Pioneer, 5/II (Port of Spain, January 1903): 2

47 The Pioneer, 6/II (Port of Spain, February 1903): 1.

48 Ibidem, 8/II (Port of Spain, February 1903): 1.

49 Idem.
} 
tration to enforce stringent quarantine restrictions against "this unfortunate colony." The writer continued that while there was controversy in Barbados over the disease, their efforts were concentrated on proving that Trinidad had small pox. Insisting that the symptoms of diseases were different, and that small pox never struck twice, it urged:

We may perhaps have to suffer the disadvantages of a rigorous quarantine, but we cannot tamely acquiescence (sic). Should quarantine be declared it would be the duty of our government to telegraph at once for a smallpox specialist from England, and then if we are right in our opinion, the Secretary of State for the Colonies would have to decide whether the Barbadian authorities would not have to pay the paper for their mistake. ${ }^{50}$

Trinidad made light of what was considered a very serious matter in Barbados. Dr. Bridger's visit and mission to Trinidad was dismissed as a joke to the Trinidadians, who asserted that Barbados moved unnecessarily from "a state of irritation to one of suspicion of foul play on our part... Mount Pelee in its anger will be a small thing compared to Bimshire roused to boiling point." ${ }^{51}$ Trinidad opinion on the matter was based on the view of respected medical practitioners on the island whose experience, it was believed, made them more knowledgeable about smallpox than those in Barbados. They did not seem likely to be receptive to any view offered by the Barbadian investigator other than the one they held.

Barbados medical investigator and officer in charge of the isolation unit at Pelican Island in Barbados arrived in Trinidad on Tuesday 17 February, 1903 to begin his investigative assignment. ${ }^{52}$

\section{The BRIDGer Report}

Dr. Bridger announced that the smallpox epidemic which afflicted Barbados is now in Trinidad in epidemic form and, according to the newspaper report, "at a rate too at which it never existed here." ${ }^{53}$ Bridger's conclusion was based on his examination of the practices, which developed since the ap-

50 Idem.

51 Excerpt from Port of Spain Gazette 1 February 1903 carried in BGCA, (Bridgetown, February 1903): 2.

52 BGCA, (Bridgetown, February 23 1903): 2.

53 Report of Dr. Bridger on Eruptive Fever in Port of Spain, NATT, Trinidad and Tobago Council Papers (CP) No. 25 of 1903: 12. 
pearance of the disease in Trinidad. He noted that no system of isolation was carried out with regard to the disease. Patients at the hospital were allowed visitors. One building, used to house patients, soon became overcrowded and patients were put on the floor. Some were refused admission and others were treated in their homes. Another building was put to use and it soon became full. In his report, ${ }^{54}$ Bridger observed that Dr. Masson of Trinidad had identified the cases in Trinidad as smallpox and this finding was immediately dismissed as absurd by the Acting Surgeon General, who said that it was an outbreak of a simple common eruptive disease, the death rate was extremely low, and lower than the norm for smallpox. Bridger diagnosed the outbreak as a mild form of smallpox and referred to the British Medical Journal which supported his diagnosis. ${ }^{55} \mathrm{He}$ commented on the lax attitude of the Trinidad authorities who, he said, did not act to prevent the spread of the disease, and in fact facilitated its spread by allowing contact between hospitalized patients and others, refusing to apply the accepted isolation procedures for infectious diseases. Thus, a rapid spread of the disease was permitted and the hospital wards became overcrowded. He observed that the Trinidad authorities sent an officer to compare the Trinidad outbreak with similar outbreaks elsewhere. For example, Acting District Medical Officer, Dr. Knox visited Jamaica, where he noted divided opinions on the nature of the disease. He also visited the infected ports of Yrapa and Guiria in Venezuela, where he observed similarities with the outbreak in Port of Spain. According to Bridger, Knox was convinced that the disease entered Trinidad from Yrapa, with which it was in daily communication and where the disease had been in full swing for over 10 months. ${ }^{56}$ These findings did not contribute to any positive action on curbing the epidemic in Trinidad.

Although the Trinidad outbreak mainly affected adults, Bridger found a number of anomalies involving children. This sparked a separate investigation into the causes of death of several children whose death certificates indicated varicella as the cause of death. These deaths were not included in the official counts of the death rate in the epidemic and certainly were not factored into the process of identification of the epidemic disease in Trinidad. He noted instances of underreporting and "definite concealment of facts known officially." 57

54 Ibidem: 16-17.

55 Ibidem: 12.

${ }^{56}$ Ibidem: 16.

57 Report on Eruptive Fever prevalent in Port of Spain Relative to two Cases of Unreported Deaths from the disease, NA, CO 28/260 11403, Enclosure No. 6 in Confidential Dispatch of 13 March, 1903. Appendix: 17-18. 
Barbados Strikes Back

As a result of these findings the Barbados government imposed quarantine restrictions against Trinidad. ${ }^{58}$ It sent copies of the Bridger report to all the governors in the region some of whom also imposed quarantine restrictions on Trinidad. ${ }^{59}$ Barbados refused the admission of third class passengers and deckers from Trinidad. First and second class passengers were only admitted if they were vaccinated and agreed to submit themselves for inspection 14 days after arrival. Inter colonial passengers passing through Trinidad were treated as coming from Trinidad. ${ }^{60}$

By letter to the government of Trinidad and Tobago, the government of Barbados outlined the intent of the Barbadian authorities. The letter stated that, based on the findings of Dr. Bridger, steamers from Trinidad would only be allowed into Barbados on the condition that no crew would be allowed to land and no clothing from the crew was to be sent ashore. Sailing vessels would only be allowed to land if the Health Officer was satisfied that all aboard the vessel were well and have been vaccinated or submit to vaccination and all crew's clothes disinfected. Crew must submit to inspection by the Barbados Harbour authorities 14 days after leaving Trinidad. ${ }^{61}$ This, in effect, was a suspension of trade.

The Mirror printed an extract from the Barbados Advocate which promised that this will bring to an end to the congratulations which a portion of the community heaped on themselves for their cleverness in enabling the colony to keep free from the trammels of the West Indian quarantine laws, for more will certainly be heard of the matter. ${ }^{62}$

The Pioneer made reference to the reactions of other Caribbean territories, some of which imposed quarantine precautions against Trinidad as a result of the verdict. While Dominica imposed quarantine sanctions, St. Vincent remained supportive. An extract from an article in the St. Vincent Sentry registered concerns about rumours circulating in the island about imminent quarantine restrictions against Trinidad and asked "why should St, Vincent be partial to Barbados?" While it was prepared to accept the majority decision, it noted that the carelessness of the Trinidad authorities led to the rapid spread of the disease. ${ }^{63}$






\section{TRINIDAD REACTS}

Dr. Bridger left Trinidad on 8 March and his report caused a furor in the medical fraternity of Trinidad. It triggered an immediate meeting of the Trinidad Medical Board under Surgeon General J De Wolf. The Board considered the Bridger report and there was emphatic rejection of the Bridger diagnosis by the majority of those gathered. They argued that the mortality rate of the disease in Port of Spain was not consistent with that of smallpox. The meeting adopted a resolution that:

"no such disease as mild smallpox exists in an epidemic form, and that the eruptive fever now prevailing in Trinidad is not smallpox." 64

Of the 35 members present 3 voted against the resolution and one, Dr. Camps, did not vote.

Another Trinidad newspaper, The Mirror was more forceful. It stated unequivocally that the disease was not smallpox since people who previously had smallpox were affected and vaccination had no effect. ${ }^{65}$ This article went on to detail the difference between Bridger's behaviour in Barbados, where he was allegedly very particular about washing and disinfecting himself and his lack of caution in Trinidad. This seemed evidence enough and prompted speculation that Bridger felt the disease was not smallpox. ${ }^{66}$ According to The Mirror, there were two distinct epidemics in Barbados. There was one case of smallpox, which came to the island from Canada and the other chicken pox as in Trinidad. Yet, it asserted, this issue gave medical men in Barbados more trouble than anything else in recent years. ${ }^{67}$

The Trinidad government, with the support of most of the local doctors refused to accept the Bridger diagnosis. Support for this stance is reflected in a newspaper article which expressed the view that "... a prosperous colony like Trinidad should not allow itself to be quarantined and shut out the world for such a benign disease is out of the question." ${ }^{68}$ In April, another issue of the same newspaper while still supportive of the position of the Trinidad govern-

\footnotetext{
${ }^{64}$ BGCA (Bridgetown, March 13 1903): 3.

65 The Mirror, 49/LX, NATT (Port of Spain, February 1903): 8-9.

${ }^{66}$ Idem.

${ }^{67}$ Ibidem, 50/LX: 8.

${ }^{68}$ The Pioneer, 11/II, NATT (Port of Spain, March 1903): 2
} 
ment, stated that there was one confirmed case of smallpox in the colony, ${ }^{69}$ and in a later issue, criticized government's inaction in handling the epidemic. ${ }^{70}$

The Trinidad reaction provided further ammunition for the Barbadians. In an article entitle "The Trinidad Mirror on Dr. Bridger's Report", the Barbados Globe and Colonial Advocate quoting The Mirror of 10 March 1903 which provided the Trinidad explanation for its rejection of the Bridger report:

That medical men from English, German, French, Swedish, Italian and American men of war have unanimously declared the disease to be not smallpox. About 3000 American sailors were on shore at one time and none contracted the disease... They walked freely in Port of Spain... We cannot accept the view of one who graduated 5 or 6 years ago over the opinion of experienced men. ${ }^{71}$

But the Barbados newspaper also carried the opinion of Dr. Masson who offered an amendment to the resolution of 10 March. He asserted that, based on the reports of Drs. Montizambert, Director General of Public Health in Ottawa and Heman-Spalding, Chief Medical Inspector of Health Department of Chicago on similar epidemics in Canada and the US, the outbreak in Trinidad was smallpox. The Masson motion was seconded by Dr. Savary and supported by Dr. Villain. ${ }^{72}$ Masson penned his opinion in a letter Bridger stating that the outbreak was "smallpox and not the common cutaneous eruption known as glasspox." He also wrote to the Ag. Governor of Trinidad in December 1902, stating his view, suggesting that Trinidad send an officer to the visit the Pelican Station in Barbados to observe the disease there and complained that, "Having given my opinion I have left no stone unturned to prove it to be right, and to have it respected, and not sneered at in public places by official heads of departments." 73

The Surgeon General of Trinidad, holding on to the dominant medical opinion explained that no steps were taken to prevent the spread of chicken pox (as he chose to call the epidemic). Since it was not smallpox there were no compulsory measures of isolation possible and the only territories to impose quarantine restrictions were St. Thomas and Barbados. ${ }^{74} \mathrm{He}$ explained that there were "wild rumours" but "with the exception of one, all of the professionals here were unanimous in the opinion that this eruptive disease

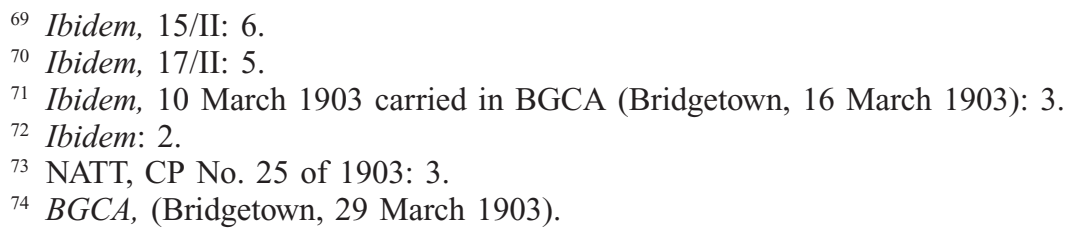


was not small pox."75 Indeed some felt that it was a disease "sui generis." Citing support from the Dickson report, he argued that it was a severe form of varicella or chicken pox.

Not to be outdone, Trinidad sent a doctor to Barbados to study the outbreak on that island. The newspaper reported that he was given every facility and promised a report that was never delivered. ${ }^{76}$

\section{The Final Dictum}

The Colonial Office was convinced by Bridger's argument. The Colonial Office minute stated that:

...the Trinidad medical service has shut their eyes, unconsciously but resolutely, to the possibility of this epidemic turning out to be smallpox, influenced by the comparative mildness of the outbreak, and by fear of the oppressive restrictions which West Indian quarantine Boards impose against an infected port.

The note was critical of the Trinidad medical community for they "shewed ...great slackness in checking the spread of the disease. ...but their practice of ignoring a disease because it is not so bad as some people believe is not at all to be recommended." 77

The disease, which assumed epidemic proportions in Trinidad was, as Dr. Bridger indicated, smallpox.

\section{The EPIDEMIC SpREADS}

In March 1903 it was evident that the epidemic, which was in its denouement in Barbados, was spreading through the Caribbean. Jamaica reported a case of smallpox on board a ship and as a result passengers on the ship were quarantined. While the ship's doctor and the Health Officer of Jamaica, Dr. Donovan, confirmed the diagnosis, Trinidad expert Dr. Knox, maintaining the Trinidad stance of denial, disagreed saying that the symptoms were the same as the cases in Trinidad. The disease, he said, was not smallpox. Dominica

75 Statement of the Surgeon General Regarding Cases of Eruptive Fever which Have Occurred in Port of Spain. Minutes and Proceedings of The General Board of Health, NATT, Royal Gazette (Port of Spain, February 19 1903): 243.

76 BGCA (Bridgetown, 8 April 1903): 2.

77 NATT, CO 28/260, No. 11403, Colonial Office Minute, 13 March 1903. 
and Guyana also notified the rest of the region that there were cases of small pox on those territories.

At a meeting of the Barbados Board of Health on Tuesday 17 March, quarantine restrictions were imposed on Guyana. The Barbados newspaper stated " for this our friends in Guyana have to thank the honesty of Trinidad officialdom." 78

As the epidemic raged in Guyana, another issue of the Barbados newspaper detailed the Guyana experience. Under the heading, "British Guiana and the Pox" it stated:

British Guiana would be lucky if it could contain the disease with the $£ 22,000$ it cost Barbados... Frequent meetings of the Guyana Medical and Sanitary Boards are held and free vaccinations are given... Chairman of the Central Board of Health, Sir David Ross, imposed isolation and declared that the disease was not smallpox. The Argosy quotes him as saying he "considers the disease to be more appropriately named chickenpox..." Yet Surgeon General, Sir David Palmer urged vaccination, which is useless in chicken pox. The Surgeon General of both Trinidad and Guyana are of similar opinion. Guyana ordered lymph from Barbados and England and the writer complained that "it is this soft feeling towards the pronouncements of brother officials in corresponding positions that have brought British Guyana staggering over a yawning precipice of uncleanliness into which it would eventually fall." Barbados responded promptly and "drank of the bitter cup of quarantine for a few weeks only when the few cases were exterminated." The disease reappeared in July then they heard of the occurrence Trinidad as early as October. Barbados believes her second outbreak was imported from Trinidad as was Guyana and the others." 79

As of March 28 Trinidad already had 1,398 cases of smallpox with 217 cases occurring in the week of March 28 but the country continued to maintain normal relations with its trading partners so facilitating disease transfer. Thus the conclusion was that Trinidad caused the small pox epidemic of 1903 to spread through the region. According to the newspaper:

Without doubt she has been the cause of all the trouble, expense and inconvenience to which these unfortunate colonies have been put, and she is not penitent enough to confess her sin and ask for forgiveness. Now Guyana is in his den as unclean. ${ }^{80}$

In his address to the Barbados Legislative Council on 15 April, 1903, Governor Hodgson declared that the epidemic which was in force since February 1902 was over as there had been no new cases since $4^{\text {th }}$ April. He established

\footnotetext{
78 BGCA (Bridgetown, 18 March 1903): 3.

${ }^{79}$ Ibidem (6 April 1903): 2.

${ }^{80}$ Idem.
} 
a Quarantine Commission to reexamine the quarantine question because the agreement of 1888 had been breached and colonies made ad hoc regulations which went "beyond that required for securing immunity from infection and was in fact an interference with carrying trade which this colony has been possessed of for so many years." ${ }^{81}$ He made strong representations to the Secretary of State seeking support for the establishment of a Commission to consider the quarantine issue to remove all the vexatious medical restrictions which hamper trade and commerce. ${ }^{82}$ This indicates, without a doubt, that medical controversies aside, there were deeper issues underlying the conflict.

\section{THE UNDERLYING ISSUES}

There was strong opprobrium in Barbados over the medical issues related to the smallpox epidemic in the region, the perception of a Trinidad cover up and the attitude of the Trinidad authorities to the whole matter. While these issues undoubtedly fanned the emotions of the army of medical and other combatants in this conflict, it is however, clear that there was more at stake than simply winning the medical war. A Trinidad newspaper noted that "Barbados has been bitterly complaining of the hard times and general depression caused by the prolonged infection and consequent quarantine declared by other islands." 83 As early as January 1903, members of the Barbados business community wrote to the Acting Colonial Secretary to request the Governor's intervention to get the quarantine restrictions against the island lifted. The members argued that the number of new cases had declined and that it appeared that the epidemic would "soon come to an end...". Noting the particularly severe restrictions applied by Trinidad, they requested the governor to communicate with

...the neighbouring governments as well as Dutch and French Guiana, calling attention to the fact that, notwithstanding the present sanitary condition of the island, the severe quarantine restrictions are unnecessarily retained by them against us, which, as His Excellency knows, are injurious affecting trade of the island in every possible direction and causing extraordinary burdens to be posed on the community, and in consequence the laboring classes, who are deprived of the means of supporting themselves and families. ${ }^{84}$

${ }^{81}$ Ibidem (15 April 1903): 2.

82 Idem.

83 The Pioneer, 4/II, NATT (Port of Spain, January 1903): 1.

${ }^{84}$ Correspondence from Governor of Barbados to the Legislative Council and House of Assembly from the Principal Mercantile Firms of the island, 30 June 1903, CO 28/ 260. 
Clearly, matters of trade were important considerations in this medical scenario. The trade embargo resulting from the Barbados declaration of an infectious disease had hurt the island's economy. Not only was there a loss of trade but the island incurred additional expenditure to deal with the epidemic itself. Support for this conclusion is obtained from other newspaper articles on the epidemic.

Referring to the adverse economic impact of quarantine restrictions on the island, one writer indicated that as a result of the declaration Barbados "rocked for four months" ${ }^{85}$ while another admitted that the island's position was "desperate." ${ }^{86}$ Querist's letter to the Editor of the Barbados Globe and Colonial Advocate of Friday January 30, $1903^{87}$ is particularly instructive in this regard. The writer refers to the trade disruption that occurred as St. Lucia imposed quarantine restrictions against Barbados after it declared the presence of smallpox on its shores. St. Lucia was the largest supplier of firewood to Barbados and an important source of cocoa, nutmeg and other spices and fruit. But it also provides evidence of inter colonial rivalry. Seeing a valuable trade opportunity, Guyana tried to take advantage of the market and ship fuel to Barbados causing St. Lucia to break its own quarantine impositions in order to regain the market. ${ }^{88}$ The writer expressed the hope that this matter would strengthen Sir Frederic Hodgson's call for a conference to deal with regional quarantine. A Barbados newspaper report on Bridger's report also made mention of the fact that "Barbados has drank bitterly of the cup of privation and want..." ${ }^{89}$ as a result of declaration of an epidemic of infectious disease on the island. The disruption of trade was in itself cause for serious concern. It affected livelihoods, disrupted families and negatively affected the market supply of the items of trade. Ultimately, it also affected the circulation of money in the economy. As indicated earlier, government revenue, in this period depended on taxes levied on imported items. Quarantine restrictions would erode government revenue particularly at a time when it could ill afford such a development. Barbados reeled under the quarantine pressure.

In his address to the Legislative Council on 15 April 1903, Governor Hodgson admitted that one "untoward result" of the smallpox epidemic was

Enclosure No. 3 in Confidential Despatch 30th June, 1903.

${ }^{85}$ Seheult, 1948: 3.

${ }^{86}$ Trinidad Royal Gazette, (Port of Spain, 19 February 1903), Minutes and Proceedings of the General Board of Health. Statement by the Surgeon General on Cases of Eruptive Fever in Pot of Spain.

${ }^{87} B G C A$, (Bridgetown, January 30 1903): 3.

${ }^{88}$ Idem.

89 "Report of the Smallpox Commissioner", BGCA, (Bridgetown, 11 March 1903): 1. 
the temporary removal of the transfer Station of the Royal Mail Steam Packet Company to Trinidad on 23 October 1902 despite his strenuous opposition. This arrangement lasted for six months before it was returned to Barbados. ${ }^{90}$ The Governor referred to "Two blows to Barbadian pride," quarantine restrictions and the loss of the headquarters of the Mail Company. ${ }^{91}$ Trinidad benefitted from these to the detriment of Barbados.

Despite reflecting the obvious hostility between the two colonies over the matter, the newspapers did draw attention to other considerations at stake in the conflict. Under the caption "The Quarantine Question" the Trinidad newspaper stated that the existing quarantine arrangements in the region were obsolete and the Barbados government, having tasted the bitter side of quarantine regulations, "was doing its utmost to bring about the adoption of more civilized methods in the West Indies." Supporting that initiative, the newspaper expressed the hope that the Trinidad government will cooperate in the effort to "establish a uniform system of protection which would take the place of the present absurd quarantine regulations.. the present diversity of practice and consequent friction" which was "neither creditable nor advantageous." 92 Dr. Masson of Trinidad agreed that quarantine was a "crude measure" whose "day was done and it was time to give it up." ${ }^{3}$

While Barbados lamented its trade loss, Guyana modified its quarantine regulations to facilitate trade. ${ }^{94}$ On the Trinidad side the prospect of trade restrictions that would come with quarantine was daunting. They would "see it as ruin" ${ }^{95}$ so Trinidad simply could not afford to allow itself to be quarantined. ${ }^{96}$ The significance of trade is also demonstrated in the Guyana/St. Lucia tiff over the Barbados trade as Guyana sought to take advantage of the situation and to protect a valuable market, St. Lucia would abandon its quarantine arrangements. This is similarly reflected in the position of St. Vincent which did not impose quarantine restrictions on Trinidad because its trade with Trinidad was important to its economy. What is striking is the way trade concerns superseded the health and welfare of the masses. This was most glaring in the case of Trinidad but was also applicable to Guyana, St. Lucia and St. Vincent where administrators shifted policy in the interest of trade.

\footnotetext{
90 Governor's Address to the Legislative Council. BGCA, (Bridgetown, 15 April 1903): 2.

91 BGCA, (Bridgetown, 19 November 1902): 3.

92 The Pioneer, 8/II, NATT (Port of Spain, February 1903): 11.

93 Ibidem, 15/II (Port of Spain, April 1903): 6.

94 BGCA (Bridgetown, 22 April 1903): 2.

95 Ibidem (19 November 1902): 3.

96 Idem.
} 


\section{CONCLUSION}

The controversy, which engulfed Barbados and Trinidad in 1902/3 over the outbreak of smallpox in the region, involved far more than medical matters. The primary consideration was economic for what was at stake was the trade that would be upset when a town, port of country was declared an infected area. It was of particular importance in the British Caribbean where there were competing economies functioning during a difficult time. Sugar, the mainstay of most of them faced market challenges and the smaller territories depended on the inter colonial trade to boost their sagging economies. Such was the level of their distress that they simply could not afford the upheaval that any disruption of this trade would bring. Faced with an unsuccessful quest for a profitable alternative to sugar production, these territories produced similar items and were dependent on the same overseas markets. While they encountered similar problems, in the competition to survive, controversies, such as the smallpox issue, fanned tensions between them and priority was given to individual concerns over regional interest. In this instance, because of its relative economic strength, the Trinidad administration assumed its views would prevail. The arrogance so demonstrated did not auger well for good inter colonial relations. The web of trade and other relationships between the colonies reflect the contradictions of dominance and dependency that were inherent in the region. The inter-colonial trade was as significant to the producers as it was to the purchasers but it also provided the facility for some to be dominant.

The events surrounding the smallpox epidemic of 1902/03 reveal the close relationship between trade and health which underscores the importance of health research to a full understanding of social and economic evolution the region. The controversy also provides a good example of uncaring colonial officialdom and the epidemic reveals the levels of squalor existing in the British Caribbean during the period providing a "social diagnosis" ${ }^{97}$ of the region. But the small pox controversy also demonstrates one of the ambiguities of the Caribbean experience- how the rivalry between the colonies in the economic sphere was juxtaposed with a recognition of the importance of cooperation on some issues. Quarantine was one such. While loyalty to self -interest was the dominant factor in inter-colonial relations, administrators were prompted to act under adverse circumstances when a united position was considered universally advantageous and more so if it was urgent. The controversy ended without any change in the material condition of the working classes and the health system remained inadequate to the needs of the population in both

97 Rosenburg, 1992: 316. 
Barbados and Trinidad. The most significant outcome of this episode was the favourable response to the call by the Governor of Barbados, and his supporters on the island, for a meeting to discuss the quarantine issue. This proposal was endorsed by the Colonial Office and a regional quarantine conference was held in 1904. This meeting produced a more practical set of quarantine regulations to guide trade activity in the region.

\section{BIBLIOGRAPHY}

Anthony, Michael, Profile Trinidad: A Historical Survey from Discovery to 1900, London, Macmillan Caribbean, 1975.

Beckles, Hilary, A History of Barbados, Cambridge, Cambridge University Press, 2006.

Brereton, Bridget, A History of Modern Trinidad, 1783-1962, Oxford, Heinemann Educational Books, 1981.

De Verteuil, Anthony, Surgery in Trinidad, Port of Spain, The Litho Press, 1996.

Duffin, Jackalyn, History of Medicine: A Scandously Short introduction, Toronto, University of Toronto Press, 2001.

Pemberton, Rita, "Puertos y Salud: Puerto España, 1850-1900," Johanna von Grafenstein Gareis (coord.), El Golfo-Caribe y sus Puertos, Tomo II, 1850-1930, México, Historia International, 2006: 93-130.

Pemberton, Rita, "Isolation an Disease: The Separation of patients in the Hospitals of Trinidad and Tobago, 1876-1938," Christopher Bonfield, Jonathan Reinarz and Teresa Huguet-Termes (eds.), Hospitals and Communities, 1100-1960, Oxford, Peter Lang, 2013: 97-122.

Richardson, Bonham, Economy and Environment in the Caribbean: Barbados and the Windwards in the Late 1800s, Kingston, Jamaica, The Press University of the West Indies, 1997.

Rosenburg, Charles, Explaining Epidemics and Other Studies in the History of Medicine, Cambridge, Cambridge University Press, 1992.

Seheult, R., A Survey of the Trinidad Medical Service, 1814-1944, Port of Spain, Government Printery, 1948.

Fecha de recepción: 1 de octubre de 2014.

Fecha de aceptación: 14 de enero de 2015. 


\section{Enfermedad y relaciones intercoloniales: La viruela en el Caribe británico, 1902-1904}

El brote de la epidemia de viruela en el Caribe a principios del siglo XX intensificó los problemas heredados del siglo XIX, el cual conllevó nuevos retos para estos territorios antillanos. Este ensayo considera la dificil controversia que surgió entre Barbados y Trinidad en relación a dicha epidemia y aborda el transcurso y las maneras en que enfrentaron dicha enfermedad ambas colonias. Se argumenta que las consecuencias económicas y sociales subyacentes a la epidemia revela el carácter de las relaciones comerciales y sanitarias y demuestra cómo aún en medio de rivalidades entre los territorios surgió una colaboración regional entre sus autoridades.

Palabras ClaVE: enfermedad; viruela; salud pública; controversia; cuarentena; comercio; relaciones intercoloniales. 